\title{
EFFECTIVENESS OF "PIK-R” PROGRAM AS AN EXTRACURRICULAR FOR HIGH/VOCATIONAL SCHOOL STUDENTS IN PREVENTING NEGATIVE BEHAVIORS OF ADOLESCENTS
}

\author{
Dwi Hastuti $^{1}{ }^{*}$, Alfiasari ${ }^{2}$, Neti Hernawati ${ }^{3}$, Oktriyanto ${ }^{4}$, and Mardiana D. Puspitasari ${ }^{5}$ \\ ${ }^{1,2,3}$ Department of Family and Consumer Sciences, Faculty of Human Ecology, \\ Bogor Agricultural University \\ ${ }^{4,5}$ Family Planning and Family Development Research and Development Center, \\ National Population and Family Planning Board \\ *e-mail: tutimartianto@yahoo.com
}

\begin{abstract}
PIK-R (Pusat Informasi Konseling Remaja) as one of the programs for adolescents is expected to be able to contribute positively in developing positive behavior and suppress the potential for negative adolescent behavior. This study aims to analyze the positive and negative behavior of high/vocational school students and their relation to knowledge, participation, and effectiveness of the PIK-R program at school. This study used a cross sectional study design involving 687 students in selected public and private high/vocational schools in Bekasi City, Indonesia. Structured questionnaire is used to measure the students' characteristics, the students' negative behavior, and the effectiveness of the PIK-R program. The study found that only $54.88 \%$ of students were aware of the PIK-R program and only $8.11 \%$ attended the program. Even so, the results of different tests show that students who take part in the PIK-R program show significantly lower negative behaviors, especially in pornography, online games, and smoking addiction. In addition, it was also found that male students tended to have higher negative behavior than female students. The results of multiple linear regression also show the real effect of the PIK-R program in suppressing the negative behaviors of adolescents.
\end{abstract}

Keywords: negative behavior, PIK-R, adolescent, senior high school, vocational high school

\section{EFEKTIVITAS PIK-R SEBAGAI EKSTRAKURIKULER SISWA SMA/SMK DALAM MENCEGAH PERILAKU NEGATIF REMAJA}

\begin{abstract}
Abstrak: PIK-R (Pusat Informasi Konseling Remaja) sebagai salah satu program bagi remaja diharapkan mampu berkontribusi positif dalam mengembangkan perilaku positif dan menekan potensi perilaku negatif remaja. Penelitian ini bertujuan untuk menganalisis perilaku positif dan negatif pada siswa SMA/SMK dan kaitannya dengan pengetahuan, keikutsertaan, dan efektivitas Program PIK-R di sekolah. Penelitian ini menggunakan desain cross sectional study dengan melibatkan 687 siswa di SMA/SMK negeri dan swasta terpilih di Kota Bekasi, Indonesia. Kuesioner terstruktur digunakan untuk mengukur karakteristik siswa, perilaku negatif siswa, dan efektivitas program PIK-R. Penelitian menemukan hanya $54.88 \%$ siswa yang mengetahui program PIK-R dan hanya $8.11 \%$ yang mengikuti program tersebut. Meskipun begitu, hasil uji beda menunjukkan bahwa siswa yang mengikuti program PIK-R lebih menunjukkan perilaku negatif yang rendah secara nyata, khususnya pada perilaku pornografi, bermain game online, dan merokok. Selain itu, juga ditemukan bahwa siswa laki-laki cenderung memiliki perilaku negatif yang lebih tinggi dibandingkan siswa perempuan. Hasil regresi linear berganda juga menunjukkan pengaruh nyata program PIK-R dalam menekan perilaku negatif remaja.
\end{abstract}

Kata Kunci: perilaku negatif, PIK-R, remaja, SMA, SMK 


\section{INTRODUCTION}

High quality adolescents certainly become one of the critical issues in balancing the quantity of adolescents who will contribute greatly to the composition of the population when the demographic bonus occurs. Especially in the $21^{\text {st }}$ century, a digital era occurs when information disclosure and the use of technology have been able to shift various community behaviors, including adolescent behavior. The World Economic Forum (2016) states that in this $21^{\text {st }}$ century, future generations need six basic skills and ten skills that show the competency and quality of individual characters. Future generations must have basic skills in literacy and reading; counting; science literacy; information, communication, and technology literacy; cultural and citizenship literacy. These competencies must be supported by high personal character qualities that include high curiosity, initiative, perseverance, adaptability, leadership, as well as social and cultural awareness.

In order to improve the quality of adolescents' life, particularly in Indonesia, the National Population and Family Planning Board in 2012 developed the GenRe (planning generation) program. One of the activities carried out in the GenRe program is the Youth Counseling Information Center (Pusat Informasi Konseling Remaja/ PIK-R). PIK-R is one of the activities in this program in order to prepare adolescents/college students for their own family life. This activity is managed from, by and for adolescents/college students to provide information and counseling services on family life planning for them. There are also other supporting activities as another part of this program. The material provided includes maturing the age of marriage, eight family functions, triad of Adolescent Reproductive Health (Kesehatan Reproduksi Remaja/KRR) (sexuality, HIV and AIDS and drugs), life skills, gender and advocacy skills and communication, information and education (Komunikasi, Informasi, dan Edukasil KIE) (National Population and Family Planning Agency/BKKBN, 2012). Ideally, this program should be quite effective in improving the quality of adolescents' lives today. PIK-R is developed in two ways, namely education and society. PIK-R developed in education way through extracurricular activities is implemented in some schools, namely schools, colleges, and boarding schools.

The quality of adolescents today will determine the quality of the nation's future. Therefore, if adolescents are currently in trouble, it could be predicted the quality of Indonesia's human resources will be even worse when demograpic bonus occurs. As results of studies conducted by Brook, Whiteman, Lisa, Shapiro, \& Cohen (1997) state, intervening in children at adolescent age as well as intervening families and their peer group environment as efforts to prevent smoking addiction in the young adult period are quite effective. The more early the interventions are carried out, the higher improvement of adolescents' quality will be and the greater the chances of adolescents having a quality life. This also confirms the potential of PIK-R in improving the quality of adolescents.

However, the implementation of PIK-R has several problems. Juliaan, Anggraeni, Winarni, ... , Ekawati, (2017) mention several PIK-R issues from the results of studies in 4 provinces in Indonesia (West Kalimantan, North Maluku, West Java, and West Sumatra); such as: (i) database of PIK-R members have not been integrated; (ii) awareness of the PIK-R existence is still low and ranges from $13 \%$ to $30 \%$; (iii) PIK-R developed in education way is not a compulsory extracurricular; and (iv) most of PIK-R developed in education way are formed at the high school level, even though the risk of adolescent marriage and deviant behavior has begun when children are under 15 years old; and (v) also IEC (information, education and 
communication) materials are less updated and informative. Based on this fact, it seems that this kind of PIK-R has many challenges in its development, especially in optimizing the quality of adolescents in developing positive behaviors and suppressing the potential of negative behavior they have. These challenges occur because adolescents tend to have a variety of impulses to be stubborn and to resist as well as a variety of experiences on facing many crises which make them not easy to be what we expect. Haikal (1983) also emphasizes that adolescence is a period of transition from childhood to adulthood and it makes adolescents still looking for life guidance and identity so that they sometimes fall into various acts that are not commendable. Even so, this period is a decisive period for someone to learn about decision making, commitment, and evaluating what has been experienced (Santrock, 2013). The hope is that optimal positive behavior and minimal negative behavior will make adolescents grow into healthier, independent, and high quality of individuals in their adulthood.

Positive behavior of adolescents can be characterized by positive characters that are raised by adolescents. Several previous studies have measured adolescent characters through several approaches (Pasaribu, Hastuti, \& Alfiasari, 2013; Karina, Hastuti, \& Alfiasari, 2013; Rahmawati, Hastuti, \& Herawati, 2014; Hastuti, Sarwoprasodjo, \& Alfiasari, 2016; Situmorang, Hastuti, \& Herawati, 2016). Meanwhile, adolescent negative behavior can refer to some juvenile delinquency behaviors that have been studied before, including delinquent behavior in students in prison (Ismayanti \& Hastuti, 2017; Fitriani \& Hastuti, 2016, bullying behavior (Karina, et.al., 2013; Pratama, Krisnatuti, \& Hastuti, 2014; Hastuti et al., 2016), cyberbullying behavior (Malihah \& Alfiasari, 2018), pornography addiction (Hardani, Hastuti, \& Yuliati, 2017), and several other behaviors such as smoking addiction, consuming liquor and drugs, free sex, online game addiction, and brawl (Hastuti et al., 2016).

As a program for adolescents, it is hoped that the PIK-R as an extracurricular activity in school is able to contribute positively in developing positive behaviors and suppress the potential negative behavior of adolescents. Edginton \& Randall (2005) suggested that one of the challenges in developing an intervention program for adolescents today is how to develop meaningful and useful programs to foster their responsibility for the learning process through which they are also responsible for their development. This confirms that adolescent programs such as PIK-R are thought to have a direct effect on suppressing negative behavior and fostering positive behavior for adolescents to have a better quality of life.

Based on the background and formulation of the problems that have been revealed, this study aims to analyze the positive and negative behavior of high/vocational school students and their relation to knowledge, participation and effectiveness of the existing PIK-R program at schools as extracurricular activities that are not mandatory. Juliaan, et.al. (2017) revealed that the most developed PIK-R is in high/vocational school. Therefore, further investigation of the existence of PIK-R in senior high schools (SMA)/vocational schools (SMK) and its role in suppressing adolescent negative behavior will become an empirical reference for the development of the PIK-R Program in the future. Furthermore, this can be used to formulate recommendations in order to improve Indonesian youth development policies in general and also to improve the development of PIK-R programs in schools specifically.

\section{METHOD}

This study used a cross-sectional study design. The research was conducted 
in four public and private high schools and vocational schools in Bekasi City, Indonesia, both those which had and did not have PIK-R program, which were selected purposively based on the updated data of PIK-R and recommendations from the Population and Family Planning Control Office, Bekasi City. The population in this study were all $10^{\text {th }}$ to $12^{\text {th }}$ grade students with a range of different students and adjusted to the conditions in the field (number of students attending and school availability at the time of data collection). The total number of selected respondents was 911 students from 4 (four) schools but after the data cleaning process was carried out only as many as 687 respondents whose data could be used, with details as follows. In the selected private vocational schools, there were 200 students from $10^{\text {th }}$ grade and $11^{\text {th }}$ grade, in selected private high schools as many as 50 students from $10^{\text {th }}$ grade to $12^{\text {th }}$ grade, in selected public high schools 224 students from $11^{\text {th }}$ and $12^{\text {th }}$ grade, as well as 213 students selected from public vocational schools from $11^{\text {th }}$ grade and $12^{\text {th }}$ grade. Data collection and reporting in the study was conducted from October to November 2018.

Primary data of this study were obtained using a questionnaire filled out by the respondents and guided by the researcher. Primary data collected in this study include: 1) characteristics of high/vocational school students, consisting of age and sex; 2) negative behavior of high/vocational school students; and 3) the effectiveness of the PIK-R program.

Negative behavioral variables of high/vocational school students were measured using instruments developed by Hastuti et al. (2016) consisting of 30 closed questions including pornography addiction, brawls behavior, online games addiction, alcohol/drugs use, cigarettes consumption, and bullying with the value of Cronbach's alpha of 0.917. The variable effectiveness of the PIK-R program was measured using instruments developed by researchers consisting of 2 (two) parts. In first section, there were three closed questions raised to see the knowledge and participation of the PIK-R program. In second part, there were 19 questions raised to measure the effectiveness of the PIK-R program with the Cronbach's alpha value of 0.907. The effectiveness of the PIK-R Program was measured in several dimensions, namely information effectiveness, effectiveness of material delivery, ease of access, utilization, and management and organization of the PIK$\mathrm{R}$ Program at schools using Likert scale starting from $1=$ very unsuitable up to $4=$ very suitable.

Furthermore, the quantitative primary data on the negative behavioral variables and the effectiveness of the PIK$\mathrm{R}$ Program were then processed into an index of 0 to 100 for the purposes of further statistical analysis. After the scoring process was an independent sample t-test to analyze the differences in the negative behavior of high/vocational school students based on gender, level of knowledge and participation of students in PIK-R. In addition, multiple linear regression tests were also conducted to analyze the influence of the characteristics of high/vocational school students and the effectiveness of the PIK-R program at schools in suppressing students' negative behavior.

\section{RESULTS AND DISCUSSION}

\section{Results}

\section{Characteristics of High/Vocational School Students}

The number of high/vocational school students involved in this study was 687 students (412 female and 275 male), more than half of high/vocational school students $(61.1 \%)$ were 16 years old with a range of ages 14 to 19 years. The average age of high/vocational school students participated in this study is 16.15 years. 


\section{PIK-R program}

Knowledge and participation. The results of the study (Figure 1) show that only 8.15 percent of high/vocational school students who participated or are actively participating in or administering PIK-R program at school (Figure 1). These results indicate that nine out of ten high/vocational school students involved in this study did not take part in PIK-R program. The results of this study are in line with Juliaan, et al., (2017) who found that one of the challenges in the implementation of the PIK-R program at schools is that PIK-R is not a compulsory extracurricular for schools. Therefore, the findings of this study confirm that the small quantities of high/vocational school students in participating PIK-R is due to the status of PIK-R as an optional extracurricular.

Based on students' knowledge about PIK-R, the results show that as many as 36.97 percent of high/vocational school students do not know about PIK-R program and 54.88 percent of high school/vocational students do not take part in the program even though they know the program (Figure 1). There is one school out of four schools where the data came from that have not had a PIK-R program yet. In addition, further results indicate that high/vocational school students are not interested in participating in PIK-R program due to lack of socialization and lack of activities held by the PIK-R program. That is why there are still some high/vocational school students who are not interested in joining the PIK-R program or even do not know about what the PIK-R program is.

Effectiveness of the PIK-R Program. The effectiveness of the PIK-R program in this study was reviewed from several dimensions, namely information effectiveness, effectiveness of material delivery, ease of access, utilization, and management and organization of PIK-R program at schools. The results (Table 1) show that the average value of total effectiveness index of PIK-R program is quite adequate, which is equal to 71.62 , with a minimum value of 50.87 and a maximum value of 100.00 .

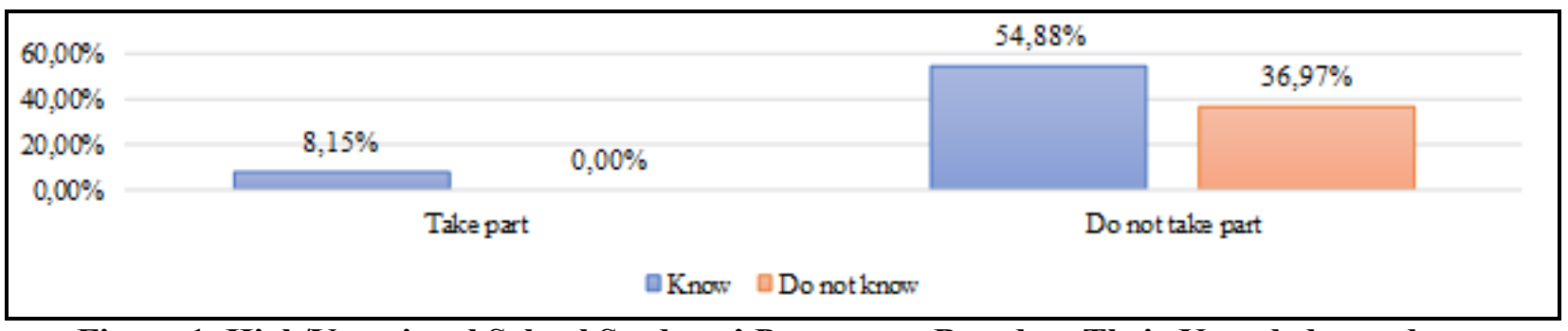

Figure 1. High/Vocational School Students' Percentage Based on Their Knowledge and Participation in PIK-R Program at Schools

Table 1. Average Values, Deviation Standard, Minimum Values, Maximum Values, and Effectiveness of PIK-R Program

\begin{tabular}{lcc}
\hline \multicolumn{1}{c}{ Variables } & Average \pm Std & Min - Max \\
\hline Information & $76,11 \pm 16,68$ & $41,67-100,00$ \\
Material Delivery & $66,67 \pm 19,33$ & $33,33-100,00$ \\
Ease of Access & $69,64 \pm 23,16$ & $33,33-100,00$ \\
Advantage & $70,73 \pm 16,53$ & $38,89-100,00$ \\
Management and Organization & $62,02 \pm 20,96$ & $16,67-100,00$ \\
\hline Total & $69,03 \pm 14,36$ & $50,87-100,00$ \\
\hline
\end{tabular}


Table 2. Average Values, Deviation Standard, Minimum Values, Maximum Values of Negative Behaviors of High/Vocational School Students

\begin{tabular}{lcc}
\hline \multicolumn{1}{c}{ Variables } & Average \pm Std & Min - Max \\
\hline Negative behaviors of adolescents & & \\
Pornography addiction & $15,39 \pm 14,68$ & $0,00-91,67$ \\
Brawls behaviour & $5,59 \pm 13,55$ & $0,00-80,00$ \\
Online game addiction & $34,70 \pm 23,79$ & $0,00-100,00$ \\
Alcohol addiction/drug use & $3,64 \pm 10,55$ & $0,00-100,00$ \\
Smoking addiction & $9,72 \pm 18,84$ & $0,00-100,00$ \\
Bullying behavior & $19,46 \pm 18,75$ & $0,00-100,00$ \\
\hline Total & $13,33 \pm 11,45$ & $0,00-75,55$ \\
\hline
\end{tabular}

Table 3. Average Values, Deviation Standard, Coefficient Values of Difference Test on Negative Behaviors of Male and Female High/Vocational School Students

\begin{tabular}{lccl}
\hline \multirow{2}{*}{ Negative behaviors } & \multicolumn{2}{c}{ Average \pm Std } & \multirow{2}{*}{ Male } \\
\cline { 2 - 3 } & $21,88 \pm 14,87$ & Female & $0,000^{* * *}$ \\
\hline Pornography addiction & $10,72 \pm 18,02$ & $11,06 \pm 12,87$ & $0,000^{* * *}$ \\
Brawls behaviour & $50,61 \pm 23,23$ & $2,17 \pm 7,79$ & $0,000^{* * *}$ \\
Online game addiction & $6,35 \pm 13,13$ & $24,09 \pm 17,41$ & $0,000^{* * *}$ \\
Alcohol addiction/drug use & $21,33 \pm 23,39$ & $1,83 \pm 7,91$ & $0,000^{* * *}$ \\
Smoking addiction & $23,66 \pm 20,03$ & $1,94 \pm 8,77$ & $0,000^{* * *}$ \\
Bullying behavior & & $16,67 \pm 17,31$ & \\
\hline
\end{tabular}

Note: ${ }^{* * *}$ significant at $\mathrm{p} \leq 0,01$

In terms of average value of each dimension, the information effectiveness has the highest average index value that is equal to 76.11. It indicates that the socialization of the PIK-R program has been quite effective in providing information on reproductive health, the dangers of drug use, the dangers of premarital sex, the dangers of HIV/AIDS, family functions and gender to high/vocational school students who attended/are currently attending PIK-R program at school. The findings also indicate that information from the program has been well received by students who participate in.

Meanwhile, management and organization has the lowest average index value compared to other dimensions, which is equal to 62.02. It turns out that high/vocational school students who participated/are currently participating in PIK-R Program assume that the program has not been able to run in accordance with the objectives that have been set, nor has it held new activities such as counseling, seminars, discussions, and etc.

\section{Adolescent Negative Behavior}

Negative behaviors examined in this study include pornography addiction, brawls behavior, online game addiction, alcohol/drug use, smoking addiction, and bullying behavior. Table 2 shows that the average value of the negative behavior index obtained is very low, which is equal to 13.33. Online game addiction has the highest average index value, which is equal to 34.70. This number shows that adolescents both men and women almost have the same desire, which is playing online games, and it is almost addictive based on the maximum values (Table 2). The results show some interesting findings, namely the presence of high/vocational school students involved in this study who have a maximum index of 100 in online game addiction, alcohol/drug use, smoking addiction, and bullying behavior. Adolescents who have 
an index value of 100 on online game addiction show that he or she is a true gamer because he or she is able to spend hours playing online games. This kind of high/vocational school students prefer playing in internet cafes because they have many friends with similar interest there and they are more comfortable making friends with those who have similar interest than others. Meanwhile, high/vocational school students who have an index value of 100 on the behavior of alcohol/drug use show that they once consumed liquor, drank the drink of his own accord, consumed alcohol more than once, had taken drugs, consumed drugs to relieve stress, took drugs to be accepted by friends, and felt satisfied and happy after taking drugs.

Similarly, an index value of 100 in terms of smoking addiction shows that the high/vocational school students have smoked and have been smoking for more than 2 years which also means it has started from elementary school or junior high school. They spent more than Rp. 100,000 in one month to buy cigarettes and they spent more than 10 cigarettes in one week. Meanwhile, the index value of
100 achieved in bullying behavior shows that high/vocational school students imply they invite friends to attack other groups, push the body of certain students roughly, hit people at school, and also humiliate certain students in front of others. The facts indicate that there are high probability of some negative behaviors on high/vocational school students. It also illustrates that a youth intervention program is really needed to create high quality adolescents and improve their quality of life.

\section{Difference Test on Negative Behaviors of High/Vocational School Students Based on Gender}

Furthermore, this study further analyzed whether there were differences in negative behavior of high/vocational school students between female and male students. As a result of difference tests (Table 3), there are significant differences between negative behaviors of female and male students of high/vocational schools $(p<0.01)$. The average value of all negative behaviors of male students is higher compared to female students.

Table 4. Average Values, Deviation Standard, and Coefficient Values of Difference Test on Negative Behaviors of Adolescents Based on Their Knowledge about PIK-R Program

\begin{tabular}{lccc}
\hline \multirow{2}{*}{ Negative behaviors } & \multicolumn{2}{c}{ Average \pm Std } & \multirow{2}{*}{$\boldsymbol{p}$-value } \\
\cline { 2 - 3 } & No information & Have information & \\
\hline Pornography addiction & $19,36 \pm 17,42$ & $13,07 \pm 12,25$ & $0,000^{* * * *}$ \\
Brawls behavior & $8,50 \pm 16,12$ & $3,88 \pm 11,47$ & $0,000^{* * *}$ \\
Online game addiction & $42,09 \pm 25,37$ & $30,37 \pm 21,69$ & $0,000^{* * *}$ \\
Alcohol addiction/drug use & $5,75 \pm 13,86$ & $2,39 \pm 7,74$ & $0,000^{* * *}$ \\
Smoking addiction & $15,64 \pm 23,87$ & $6,25 \pm 14,04$ & $0,000^{* * *}$ \\
Bullying behavior & $21,78 \pm 19,60$ & $18,11 \pm 18,12$ & $0,015^{* *}$ \\
\hline
\end{tabular}

Note: ${ }^{* * *}$ significant at $\mathrm{p} \leq 0.01 ; * *$ significant at $\mathrm{p} \leq 0,05$

\section{Difference Test on Negative Behaviors of High/Vocational School Students based on Their Knowledge about PIK-R Program}

Knowledge is one of the important factors in influencing a person's behavior.
As a result of behavior difference test (Table 4), there are significant differences between negative behaviors of students who do not know about PIK-R program with those who know about the program $(\mathrm{p}<0.01 ; \mathrm{p}<0.05)$. The average value of all negative behaviors of students who do not 
know about PIK-R program is higher than those who know about the program. This is an interesting finding considering the percentage of students' participation in the program was only $8.15 \%$ even though
$54.88 \%$ of students already knew about PIK-R program. This small proportion of students have low negative behaviors.

Table 5. Average Values, Deviation Standard, and Coefficient Values of Difference Test on Negative Behaviors of Adolescents Based on Their Participation in PIK-R Program

\begin{tabular}{lccc}
\hline \multirow{2}{*}{ Negative behaviors } & \multicolumn{2}{c}{ Average \pm Std } & \multirow{2}{*}{-value } \\
\cline { 2 - 3 } & No participation & Have a participation & \\
\hline Pornography addiction & $15,67 \pm 14,86$ & $12,20 \pm 12,20$ & $0,049^{* *}$ \\
Brawls behavior & $5,68 \pm 13,73$ & $4,52 \pm 11,45$ & 0,477 \\
Online game addiction & $35,33 \pm 24,05$ & $27,68 \pm 19,47$ & $0,007^{* * *}$ \\
Alcohol addiction/drug use & $3,75 \pm 10,77$ & $2,38 \pm 7,48$ & 0,212 \\
Smoking addiction & $10,25 \pm 19,39$ & $3,81 \pm 9,06$ & $0,000^{* * *}$ \\
Bullying behavior & $19,59 \pm 18,78$ & $18,09 \pm 18,49$ & 0,565 \\
\hline
\end{tabular}

Note: $* * *$ significant at $\mathrm{p} \leq 0,01$

Table 6. Regression Coefficients to Analyse the Effect of Students' Characteristics and Effectiveness of PIK-R Program on Negative Behaviors of High/Vocational School Students

\begin{tabular}{|c|c|c|c|}
\hline \multirow[b]{2}{*}{ Variables } & \multicolumn{2}{|c|}{ Coefficients } & \multirow[b]{2}{*}{ Sig } \\
\hline & $\begin{array}{l}\text { Not standardized } \\
\text { (B) }\end{array}$ & $\begin{array}{c}\text { Standardized } \\
(\boldsymbol{\beta})\end{array}$ & \\
\hline Constanta & 38,992 & & $0,000 * * *$ \\
\hline Age (years old) & $-0,412$ & $-0,026$ & 0,434 \\
\hline Sex $($ dummy $1=$ male $; 2=$ female $)$ & $-11,739$ & $-0,503$ & $0,000 * * *$ \\
\hline $\begin{array}{l}\text { Effectiveness of PIK-R program } \\
\text { (index) }\end{array}$ & -0.039 & -0.069 & $0.038 * *$ \\
\hline F-test $(p)$ & & 81,448 & \\
\hline Adjusted R Square & & 0,260 & \\
\hline Sig & & $0,000 * * *$ & \\
\hline
\end{tabular}

Difference Tests on Negative Behaviors of Adolescents Based on the Participation of High/Vocational School Students in PIK-R Program

This study not only gives knowledge but also analyzed further whether there were differences on negative behaviors of students who participated in PIK-R program and those who did not participate in. Table 5 shows that there were significant differences on negative behaviors of students who did not participate in PIK-R program and students participating in the program $(\mathrm{p}<0.01 ; \mathrm{p}$
$<0.05)$. The average for all negative behaviors of students who do not participate in the PIK-R program is higher compared to those participating in PIK-R program. On the other hand, there was no significant difference on brawl behavior, alcohol/drug use, and bullying behavior of students who did not participate in PIK-R program and students participating in PIK$\mathrm{R}$ program. The results (Table 5) indicate that pornography addiction, online game addiction, and smoking addiction of students who participated in the PIK-R are significantly different from those who did 
not participate in PIK-R program. It also showed that the three behaviors were

\section{Effect of PIK-R Program on Negative Behaviors of High/Vocational School Students}

The results (Table 6) show that the sex of high/vocational school students and the effectiveness of the PIK-R program have a significant negative effect on adolescent negative behaviors. This can be interpreted that negative behaviors are more likely to be formed in male adolescents by 0.503 points compared to female adolescents $(\beta=-0.503 ; \mathrm{p}<0.01)$, and each increase in one unit effectiveness of PIK-R program will reduce adolescents' negative behaviors by 0.069 points $(\beta=$ $0,069 ; \mathrm{p}<0.05)$. Furthermore, the coefficient of determination (Adjusted $\mathrm{R}$ Square) for the following regression equation model explains that 26.0 percent of the negative behavior variants of students can be explained by changes in adolescent characteristic variables and the effectiveness of the PIK-R program contained in the model, while the remaining 74.0 percent of the negative behaviors of students is influenced by other variables which was not examined in this study.

\section{Discussion}

Based on data from the Indonesian Demographic and Health Survey (2012), $33.3 \%$ of female adolescents and $34.5 \%$ of male adolescent had started dating before they were 15 years old. Then the number of premarital sex carried out by young men aged 15-19 years in 2007 was $3.7 \%$, increasing to $4.5 \%$ in 2012 , whereas in young men aged 20-24 years had premarital sex of $10.5 \%$ in 2007 increased to $14.6 \%$ in 2012 . Similarly, the number of girls aged 20-24 who had premarital sex increased from $1.4 \%$ in 2007 to $1,8 \%$ in 2012, while adolescent number who had premarital sex at the age of 15-19 years was $1.3 \%$ in 2007 and decreased to $0.7 \%$ sensitive issues that should be solved through PIK-R program. in 2012. In addition, the use of cigarettes and drugs is also extensive among teenagers. Nearly a quarter of Indonesian youth (24.25 percent) in 2015 became heavy smokers (2015 Indonesian Youth Statistics). The survey conducted by the Indonesian Internet Service Providers Association (APJII) in 2017 on 2,500 Indonesian residents aged at least 13 years old in six major regions of Indonesia found that $16.68 \%$ of internet users were 13-18 years old. These facts show that programs to optimize the development of adolescents are very necessary, especially in the digital era like today. Sheehan, Sweeny, Rasmussen, Wills, Friedman, Mahon, ... Laski (2017) report that investments made in adolescents especially in the fields of health and education will not only change the life of adolescents who come from poor families but it will also get economic returns and social which has a positive impact on the quality of adolescent life. Therefore, short, medium and long-term investment programs aimed at adolescents ideally will be able to improve quality of an individual. It will also have a positive impact on their social life and enable them to improve the quality life of their nation.

To be able to develop programs that can improve the quality of adolescents' life, it is necessary to examine the extent to which studies have been carried out in order to provide an empirical framework as a foundation of a program development. Hastuti et al. (2016) state that several negative behavioral problems are carried out by adolescents including smoking addiction, alcohol and drug use, free sex, online game addiction, brawls behavior, and bullying behavior. These behaviors are performed by teenagers not only in urban areas but also in rural areas in Indonesia. Studies conducted in American adolescents, both white and black, find that teens who consume alcohol increase the 
risk of sexual behavior and the risk of sexually transmitted diseases will be greater (Khan, Maria, Berger, Wells, \& Cleland 2012). In adolescents, some violent behaviors carried out by adolescents actually begin in the early period of adolescent even though this is influenced by various factors. Another study conducted by Ellickson \& McGuigan (2000) states that female adolescents who have low self-esteem in the early adolescent period will tend to engage in violent behavior during late adolescent. Meanwhile, in male adolescents, moving out to another school at elementary school increases the opportunity to engage in various violent behaviors during adolescent. In addition, adolescents who were in the early period of adolescent use drugs and marijuana both individually and in groups increase their involvement in violent behaviors when they are at late adolescents.

In line with the results of previous studies, this study proves that although the average of negative behavior index ranges from 3.64-34.70, students in this study still have an index of 100 . These numbers indicate that negative behaviors measured in this study still occurs and have a high risk. According to Martyniuk \& Stulhofer (2018), negative behaviors on adolescents is closely related to social norms in the surrounding community. The results also find that male students had a tendency to engage in pornography addiction, online game addiction, and smoking behavior than female students. This finding is also in line with Carlo, Raffaelli, Laible, \& Meyer (1999) who find that male adolescents have a higher level of aggressiveness compared to female adolescents due to differences in characteristics between male and female adolescents. It is also due to a lower sense of empathy on male adolescents compared to female adolescents. While Rahyani, Utarini, Wilopo, \& Hakimi (2012) in their study state that the cause of male adolescents more involved in negative behavior is influenced by their limited ability to think logically, difficulty in regulating emotions, and they are more susceptible to peer interaction.

Furthermore, the results of this study also find that the negative behaviors of students who know PIK-R program are significantly different from those who do not know about PIK-R program as well as negative behaviors of students who do not participate in PIK-R program and those who participate in PIK-R program. This is an interesting finding considering the participation of students in PIK-R program found in this study is only $8.15 \%$ even though $54.88 \%$ of students already knew the existence of PIK-R program. Even though there is only a small proportion of students who know about PIK-R program and they attend it, these students tend to have lower negative behaviors. The PIK-R program at school was developed as an optional extracurricular. This also allows a very low number of students to participate in the Program, which is only one out of ten students. This is also in line with the findings of a previous study that one of the problems faced in the implementation of PIK-R program at school is the status that this program has not yet required as a compulsory extracurricular (Juliaan, et. al., 2017). Data from the field also show that the lack of socialization regarding the PIK$\mathrm{R}$ program and also the inactivity of the program in developing school activities is the main reason why students are less interested in joining the program.

According to the guidelines of PIK$\mathrm{R}$ program implementation (BKKBN, 2012), there is a comprehensive material that includes maturing the age of marriage, eight family functions, triad of Adolescent Reproductive Health/KRR (sexuality, HIV/AIDS and drugs), life skills, gender, and advocacy skills and IEC (information, education and communication). A previous study conducted by Juliana, Rahmayanti, \& Astika (2018) state that there is no significant differences on the knowledge and attitudes of adolescents who 
participate in PIK-R program and adolescents who do not participate in the program on reproductive health. The reason is adolescents who did not participate in the program have received reproductive health knowledge from family, friends, teachers, and so on.

However, this study finds something differently that based on the participation of students in PIK-R program, there are significant differences on students' negative behaviors, especially in pornography addiction, online game addiction, and smoking behavior. These results indicate that before and after the existence of the program, the three behaviors of students are quite sensitive and significantly different. In this era of information, communication and technology, teenagers' access to pornography and online games is quite excellent, not only for adults but also for children. This study proves that students participating in PIK-R can be differentiated from those who do not participate in PIK-R by the quality of their behavior. Their access to pornography is lower. Likewise, smoking behavior is the most common behavior and it can be easily found around us, not only in the adult environment but also in the environment of children and adolescents. Smoking behavior that is very high risk on health, economy, and adolescent psychology can be controlled by the participation of students in PIK-R program.

In addition, the characteristics of students that include age and sex as well as PIK-R program measured in terms of effectiveness which include effectiveness of information and material delivery, ease of access, utilization, also management and organization of PIK-R program significantly affect on decreasing adolescent negative behaviors with an opportunity of $26.0 \%$. These results indicate that although only one out of ten students in this study found who participated in PIK-R program, they were able to provide considerable opportunities. The R2 adjusted number also shows that 74.0 percent of students' negative behaviors is influenced by other variables not examined in this study. Adolescent negative behavior which is also often identified with antisocial behavior can occur due to genetic factors including age, gender and environment, such as the relationship between adolescents and mothers, support from parents, peer groups, and teachers. (Ma, Shek, Ping, \& Bun, 2000; de Kemp, Overbeek, G., de Wied, Engels, \& Scholte, 2007; Tuvblad, Narusyte, Grann, Sarnecki, \& Lichtenstein, 2011; Crocetti, Moscatelli, Jolien Van, Keijsers, Pol, Koot , ... Branje, 2016). In addition, Hastuti et al. (2016) find that positive character possessed by teenagers was also closely related to the lower variety of juvenile delinquency behaviors. Even though in the teenage period the interaction of adolescents with their parents diminishes but the role of parents still plays an important role. This is proved in several previous studies which found a high influence of parenting on various qualities of adolescent growth (Pasaribu et al. 2013; Asilah \& Hastuti, 2013; Ramadhianti \& Alfiasari, 2017; Novianti \& Alfiasari, 2017). Some of the results of these studies show that various factors both from adolescent internal factors and the environment influence the formation of various juvenile delinquent behaviors. Therefore, efforts to reduce the risk of various adolescent negative behaviors can be done through prevention efforts, one of which is through PIK- $\mathrm{R}$ program at schools.

This study confirms the effectiveness of PIK-R program in suppressing adolescent negative behaviors. PIK-R is one of the activities of the GenRe program in the context of preparing family life for adolescents/college students managed from, managed by and managed for adolescents/college students to provide 
information and counseling services on family life planning for adolescents/college students. In the future, the development of PIK-R program as a compulsory extracurricular could be carried out by presenting more contemporary materials which become a strategic issue that can be implemented.

\section{CONCLUSION}

The results show that only $54.88 \%$ of high/vocational school students are aware of PIK-R program and only $8.11 \%$ are participating in the program. The results of difference tests show that high/vocational school students who take part in PIK-R program show significantly lower negative behaviors, especially in pornography addiction, online game addiction, and smoking addiction. In addition, male students tended to have higher negative behaviors than female students. The multiple linear regression results show the real effect of PIK-R program in suppressing the negative behaviors of adolescents. It indicates that PIK-R program is an effective program to suppress adolescent negative behaviors. It is hoped that each school can hold a PIK-R extracurricular activity and make a routine agenda in delivering PIK-R materials. The objective is giving knowledge about the adverse effects of pornography, brawls behavior, online game addiction, drug use, smoking addiction, and bullying behavior to high/vocational school students.

\section{ACKNOWLEDGEMENT}

This work would not have been possible without data and information from the Deputy of Research, Development and Training, National Population and Family Planning Agency (BKKBN) of the Republic of Indonesia, and the Population and Family Planning Control Office in Bekasi City.

\section{REFERENCES}

APJII. Asosiasi Penyelenggara Jasa Internet Indonesia. (2017). Infografis survey penetrasi dan perilaku pengguna internet Indonesia 2017. Retrieved from http://apjii.or.id.

Asilah, A. \& Hastuti, D. (2013). Hubungan tingkat stres ibu dan pengasuhan penerimaan penolakan dengan konsep diri remaja pada keluarga bercerai. Jurnal Ilmu Keluarga \& Konsumen, 7(1), 10-18. doi:10.24156/jikk.2014.7.1.10.

BKKBN. Badan Kependudukan dan Keluarga Berencana Nasional. (2012). Pedoman Pengelolaan Pusat Informasi dan Konseling Remaja dan Mahasiswa (PIK-R/M). Retrieved from http://nad.bkkbn. go.id/data/Documents/Panduan\%20P IK-KRR\%20Percontohan.pdf.

BPS. Badan Pusat Statistik. 2015. Hasil survei penduduk antar sensus 2015. Retrieved from http://www.bps. go.id.

BPS. (2015). Statistik pemuda Indonesia (Hasil survei sosial ekonomi sosial) tahun 2015. Retrieved from: http://www.bps.go.id.

Brook, J. S., Whiteman, M., Lisa, J. C., Shapiro, J., \& Cohen, P. (1997). Cigarette smoking in young adults: Childhood and adolescent personality, familial, and peer antecedents. The Journal of Genetic Psychology, 158(2), 172-188. doi: $10.1080 / 00221329709596660$.

Carlo, G., Raffaelli, M., Laible, D. J., \& Meyer, K. A. (1999). Why are girls less physically aggressive than boys? Personality and parenting mediators of physical aggression. Sex 
Roles, 40(9-10),

711-729.

doi:10.1023/A:1018856601513.

Crocetti, E., Moscatelli, S., Jolien Van, d. G., Keijsers, L., Pol, v. L., Koot, H. M., ... Branje, S. (2016). The dynamic interplay among maternal empathy, quality of motheradolescent relationship, and adolescent antisocial behaviors: New insights from a six-wave longitudinal multi-informant study. PLoS One, 11(3), 1-17. doi: 10.1371/journal.pone.0150009.

de Kemp RA., Overbeek G., de Wied M., Engels R. C., \& Scholte R. H. (2007). Early adolescent empathy, parental support, and antisocial behavior. The Journal of Genetic Psychology, 168(1), 5-18. doi: 10.3200/GNTP.168.1.5-18.

Edginton, C. R., \& Randall, S. W. (2005). Youth services: Strategies for programming. Journal of Physical Education, Recreation \& Dance, 76(9), 19-24. doi:10.1080/07303084.2005.106083 06.

Ellickson, P. L., \& McGuigan, K. A. (2000). Early predictors of adolescent violence. American Journal of Public Health, 90(4), 566-72. doi:10.2105/AJPH.90.4.566.

Fitriani, W., \& Hastuti, D. (2017). Pengaruh kelekatan remaja dengan ibu, ayah, dan teman sebaya terhadap kenakalan remaja di Lembaga Pembinaan Khusus Anak (LPKA) kelas II Bandung. Jurnal ilmu keluarga \& konsumen, 9(3), 206217. doi:10.24156/jikk.2016.9.3.206.

Haikal, H. (1983). Remaja, masa yang makin "membengkak".Cakrawala Pendidikan, 2(2), 90-106. doi:10.21831/cp.v2i2.7553.
Hardani, R., Hastuti, D., \& Yuliati, L, N., (2017). Pengaruh kelekatan anak dengan orang tua, guru, teman, dan kontrol diri terhadap perilaku pornografi anak SMP. Jurnal Ilmu Keluarga dan Konsumen, 10(2), 120-131.

doi:10.24156/jikk.2017.10.2.120.

Hastuti, D., Sarwoprasodjo S., \& Alfiasari. (2016). An integration of family and school on strengthening the character of teenager in indonesia: It's a must. Journal of Child Development Studies, 1(1), 13-27. doi:10.29244/jcds.1.01.13-26.

Ismayanti, P., \& Hastuti, D. (2017). Kenakalan pada remaja andikpas (anak didik lapas): Pengaruh komunikasi orang tua atau selfesteem? Jurnal Ilmu Keluarga \& Konsumen, 10(1), 36-46. doi:10.24156/jikk.2017.10.1.36.

Juliaan, F., Anggraeni, M., Winarni, E., ..., Ekawati, R. (2017). Peranan PIK-R dalam menurunkan angka kelahiran usia remaja dan pendewasaan usia perkawinan. Pusat Penelitian dan Pengembangan KB dan KS BKKBN RI.

Juliana, M. I., Rahmayanti, M. D., \& Astika, M. E. (2018). Tingkat pengetahuan dan sikap siswa smp tentang kesehatan reproduksi remaja berdasarkan keikutsertaan pada program pusat informasi dan konseling-remaja (PIK-R). Dunia Keperawatan, 6(2), $\quad$ 97-106. doi:10.20527/dk.v6i2.5556.

Karina, K., Hastuti, D., \& Alfiasari, A. (2013). Perilaku bullying dan karakter remaja serta kaitannya dengan karakteristik keluarga dan peer group. Jurnal Ilmu Keluarga \& Konsumen, 6(1), 20-29. doi: 10.24156/jikk.2013.6.1.20. 
Khan, Maria R., Berger, A. T., Wells, B. E., \& Cleland, C. M. (2012). Longitudinal associations between adolescent alcohol use and adulthood sexual risk behavior and sexually transmitted infection in the United States: Assessment of differences by race. American Journal of Public Health, 102(5), 867-876. doi: 10.2105/AJPH.2011.300373.

Ma, H. K., Shek, D. T. L., Ping, C. C., \& Bun, C. O. (2000). Parental, peer, and teacher influences on the social behavior of Hong Kong Chinese adolescents. The Journal of Genetic Psychology, 161(1), 65-78. doi: $10.1080 / 00221320009596695$.

Malihah, Z., \& Alfiasari. (2018). Perilaku cyberbullying pada remaja dan kaitannya dengan kontrol diri dan komunikasi orang tua. Jurnal Ilmu Keluarga \& Konsumen, 11(2), 145156.

doi: 10.24156/jikk.2018.11.2.145.

Martyniuk, U., \& Štulhofer, A. (2018). A longitudinal exploration of the relationship between pornography use and sexual permissiveness in female and male adolescents. Journal of adolescence, 69, 80-87. doi: 10.1016/j.adolescence.2018.09.006.

Novianti, D., S., \& Alfiasari. (2017). Kepuasan hidup mahasiswa tingkat pertama: kaitannya dengan karakter mahasiswa dan gaya pengasuhan orang tua. Jurnal Ilmu Keluarga \& Konsumen, 10(1), 13-23. doi: 10.24156/jikk.2017.10.1.13.

Pasaribu R. M., Hastuti D., \& Alfiasari. (2013). Gaya pengasuhan permisif dan rendahnya sosialisasi nilai dalam keluarga berisiko terhadap penurunan karakter remaja. Jurnal Ilmu Keluarga dan Konsumen, 6(3),
163-171.

doi:

10.24156/jikk.2013.6.3.163.

Pratama, A., Krisnatuti, D., \& Hastuti, D. (2014). Gaya pengasuhan otoriter dan perilaku bullying di sekolah menurunkan self-esteem anak usia sekolah. Jurnal Ilmu Keluarga \& Konsumen, $\quad 7(2), \quad 75-82$. doi:10.24156/jikk.2014.7.2.75.

Rahmawati, S. H., Hastuti, D., \& Herawati, T. (2014). Analysis of social media's access; relation to character of vocational student in Bogor. Jurnal Ilmu Keluarga \& Konsumen, 7(2), 67-74. doi:10.24156/jikk.2014.7.2.67.

Rahyani, K. Y., Utarini, A., Wilopo, S. A., \& Hakimi, M. (2012). Perilaku seks pranikah remaja. Kesmas: National Public Health Journal,7(4), 180185. doi: 10.21109/kesmas.v7i4.53.

Ramadhianti N., \& Alfiasari. (2017). Temperamen, interaksi ibu-remaja, dan kecerdasan emosi remaja pada keluarga dengan ibu bekerja di perdesaan. Jurnal Ilmu Keluarga \& Konsumen, 10(2), 132-142. doi: 10.24156/jikk.2017.10.2.132.

Santrock, J. W. (2013). Life-span development (14th Ed.). New York, NY: McGrawHill.

Situmorang, Z. R., Hastuti, D., \& Herawati, T. (2016). Pengaruh kelekatan dan komunikasi dengan orang tua terhadap karakter remaja perdesaan. Jurnal Ilmu Keluarga \& Konsumen, 9(2), 113-123. doi:10.24156/jikk.2016.9.2.113.

Sheehan, P., Sweeny, K., Rasmussen, B., Wils, A., Friedman, H. S., Mahon, J., . . . Laski, L. (2017). Building the foundations for sustainable development: A case for global 
investment in the capabilities of adolescents. The Lancet, 390(10104), 1792-1806. doi:10.1016/S0140-6736(17)308723.

SDKI. Survei Demografi dan Kesehatan Indonesia. (2012). Kesehatan reproduksi remaja. Retrieved from http://sdki.bkkbn.go.id/.

Tuvblad, C., Narusyte, J., Grann, M., Sarnecki, J., \& Lichtenstein, P. (2011). The genetic and environmental etiology of antisocial behavior from childhood to emerging adulthood. Behavior Genetics, 41(5), 629-40. doi:10.1007/s10519-011-9463-4.

World Economic Forum. (2016, Maret). New vision for education: fostering social and emotional learning through technology: Prepared in collaboration with The Boston Consulting Group. Report, Geneva, Switzerland. 